\title{
SOME PHYSIOLOGICAL RESPONSES OF SHAMI GOATS TO FEEDING SALT TOLERANT FODDER CROPS DURING PREGNANCY UNDER SOUTH SINAI CONDITIONS
}

\author{
Hanan Z. Amer, \\ ${ }^{1}$ Animal and Poultry Physiology Department, Desert Research Center, Matarieya, Cairo, Egypt \\ ${ }^{2}$ Department of Biology- Faculty of Science- Jazan University- Kingdom of Saudi Arabia
}

(Received 3/2/2016, accepted 22/3/2016)

\section{SUMMARY}

$\mathrm{T}$ lo study the effect of feeding salt tolerant fodder crops during pregnancy under south Sinai conditions (Ras Sudr station) on some physiological responses of Shami goats, fourteen Shami doe goats aged 2.5-3.0 years old with averaged $25.07 \pm 2.44 \mathrm{~kg}$ body weight were used and randomly divided into two equal groups (7 animals each) as follow: The first group (G1) fed berseem hay as control, while the second one (G2) fed a mixture of Atriplex nummularia $(50 \%)+$ Sorghum bicolor $(25 \%)+$ Pearl millet $(25 \%)$. Both groups were supplemented with concentrate feed mixture (CDM). Live body weight changes and daily gain were recorded biweekly. Blood samples were collected from the all animals during dry, gestation (early, mid and late) for the determination of the biochemical parameters, electrolytes and hormones. The results revealed that live body weight and weight gain of control and the treated groups of doe goats were similar. Treated goats had slightly insignificant lower concentrations of TP, AL, GL, A/G ratio, and cholesterol with significant effect of pregnancy on total proteins profile. The mean values of TP, AL and GL significantly decreased $(\mathrm{P}<0.05)$ with advancing gestation periods. Glucose and aldosterone concentrations in treated pregnant goats showed significant $(\mathrm{P}<0.01)$ decrease as compared to the control animals. The significant interaction between treatment and physiological stage for ALT, ALP enzyme and insulin concentrations was for the reverse effect of each source of variance. While ALT, ALP enzyme and insulin increased by feeding salt tolerant plants but they were decreased by advancing pregnancy stages. Feeding a mixture of salt tolerant plants significantly decreased $(\mathrm{P}<0.01)$ the concentrations of urea and creatinine in comparison with control diet with insignificant increased throughout the gestation periods. The concentration of $\mathrm{Na}$ was affected significantly $(\mathrm{P}<0.01)$ by treatment and physiological status where it showed significant increase in the treated animals during different pregnancy stages. Potassium concentration was increased significantly from dry to reach peak during mid-gestation then declined again during late gestation compared to control animals. These results might indicate that salt tolerant plants could be a feasible solution to minimize the problem of animal feed shortage under arid conditions of Southern Sinai without sever physiological problems. These problems might be amplified due to the stress of pregnancy.

Keywords: Shami doe goats; salt tolerant plants, Atriplex nummularia, Sorghum bicolor, Pearl millet; pregnancy; physiological parameters; Sinai.

\section{INTRODUCTION}

Animal production in the Egyptian deserts is mainly based on natural vegetation as animal feeds. Small ruminants are the most dominant livestock in Sinai desert. They play an important role in the social life and economic status of Bedouins. Shami goats, in particular, are characterized by their high milk production and faster growth rate in addition to their large size relative to Baladi goats (Zarkawi and Soukouti, 2004). Feeding Shami does during physiological stresses; gestation and lactation; seemed to be a great challenge to spread such breed in desert areas whenever grazing is the only feed source (Badawy and Youssef, 2008). Shortage of feeds and water are the main limiting factors for sufficient animal production under the arid conditions of South Sinai in Egypt (Abdul-Aziz et al., 2001) and is considered the main constraint to improve livestock productivity. Dry regions in Egypt suffer from a chronic shortage of fodder crops production due to several environmental factors, particularly salinity stress in soils and ground water. Bedouins spend a considerable amount of money to buy and transport other feed ingredients from the Nile valley region, which puts an additional burden on the economic situation of Bedouins and have an impact on the feed gab in the Nile valley areas (Alsheikh et al., 2012). The 
rangelands of Sinai are an open shrub vegetation, most likely salt and/or drought tolerant plant; therefore, intensive efforts have been directed to use these plants as animal feed resources (El Shaer, 2006).

Feeding halophytes is a feasible solution to minimize the problem of animal feed shortage in desert areas. Therefore, proper range management and utilization of halophytes as an animal feed should have the priority of the development plan (Abd El-Rahman et al., 2008). Halophytes have the advantage of tolerating high salt levels in the saline lands, have economic potentialities in the arid and semi-arid areas (El Shaer, 2000) and provide a valuable reserve feed for grazing animals particularly under drought conditions or fill regular gaps in feed supply caused by seasonal conditions (ICBA, 2006). The most available halophytic species are atriplex, which could be planted in such areas. This plant can be utilized as a main or secondary source of feed in periods when the availability of conventional forage is low (Alicata et al., 2002). In addition, feeding Pearl millet and sorghum are among the most potential salttolerant grass species as good quality fodders for small ruminants in Egypt and other countries in the Near East (Anon, 2009).

Salinity of salt tolerant plants and pregnancy are known to be stress factors on animal (Amer et al., 2014) and during pregnancy, maternal tissues are involved in providing energy for reproduction processes, which may affect blood serum chemistry values (Yokus et al., 2006) and the effect of the feeding salt tolerant fodder crops on the physiology of pregnant Shami goats is not fully understood. Most researches focused only on the effect of feeding salt tolerant fodder crops on non-pregnant animals and the others focused on the effect of physiological status on biochemical parameters but little studies was conducted the interaction between feeding salt tolerant fodder crops and physiological stages. Therefore, the present study was designed to gain detailed information on the changes in some physiological and biochemical parameters in doe Shami goats during pregnancy due to the impact of feeding salt tolerant fodder crops under South Sinai conditions.

\section{MATERIALS AND METHODS}

This study was conducted at South Sinai Station (Ras Sudr) which belongs to Desert Researcher Center, Ministry of Agriculture and Land Reclamation, Egypt, in order to monitor the effect of feeding a sun-dried chopped mixture of salt tolerant fodder crops on some physiological and biochemical parameters of Shami goats during different gestation stages. Fourteen Shami doe goats aged 2.5- 3.0 years old with averaged $25.07 \pm 2.44 \mathrm{~kg}$ body weight were randomly divided into two equal groups (7 animals each). The first group (G1) fed berseem hay (Trifolium alexandrinum, $4^{\text {th }}$ cut) and was used as control, while the second group (G2) fed a mixture of Atriplex nummularia (50\%) plus Sorghum bicolor (25\%) and Pearl millet (25\%). The chemical composition of Atriplex nummularia, sorghum bicolor and Pearl millet and berseem hay was determined according to A.O.A.C. (1985).

The experimental animals were housed indoors inside separate semi-closed pens and were weighed biweekly up to end of the experiment. Drinking clean fresh water was made available twice a day over the experimental period. Both groups were provided by concentrate feed mixture (CFM). All experimental animals were fed their nutrient requirements according to Kearl (1982).

Jugular blood samples were collected into heparinized tube $(10 \mathrm{ml})$ from all experimental animals in early morning just before offering ration and water during dry and different gestation periods. Heparinized blood samples were centrifuged at $3000 \mathrm{rpm}$ for $30 \mathrm{~min}$. Pipetting off plasma was carried out without disturbing the white buffy layer. Plasma samples were separated, labeled and stored in Eppendorf vials at $-80^{\circ} \mathrm{C}$ for pending analysis of the investigated biochemical parameters. Colorimetric determination of total proteins (TP) and albumin (AL) in plasma were carried out by a test kits supplied by Egyptian-American Company for Laboratory Services according to method described by Gornall et al. (1949) and Doumas et al. (1971), respectively. Values of globulin (Gl) and A/G ratio were calculated. Glucose concentration was analyzed according to Tietz (1986). Assay of liver functions was monitored by colorimetric determination of aspartate aminotransferase (AST) and alanine aminotransferase (ALT) activities according to the method of Reitman and Frankel (1957). Total cholesterol (CHO) and alkaline phosphatase concentration (ALP) was determined according to Roeschlau et al. (1974); Belfield and Goldberg (1971) respectively. Indicators for kidney functions were determined using biodiagnostic kits according to Fawcett and Soctt (1960) and Schirmeister et al. (1964) for colorimetric determination of plasma urea and kinetic determination of creatinine concentrations, respectively. Blood sodium (Na) and Potassium (K) were determined according to Trinder (1951) and Sunderman and Sunderman (1958), respectively. Direct radioimmunoassay technique (RIA) was performed for plasma insulin and aldosterone hormones using ready antibody coated tubes kits manufactured by Immunotech, Beckman Counter Company, France. Data were analyzed using General Linear Model Procedure (SAS, 2004) for repeated measurements. 


\section{RESULTS and DISCUSSION}

\section{Chemical composition of feed stuffs:}

Considerable variations were observed among the chemical composition of Atriplex nummularia, sorghum bicolor and Pearl millet when compared to berseem hay. The results presented in Table (1) showed that dry matter (DM), crude fiber (CF) and nitrogen free extract (NFE) contents were higher in Berseem hay (100, 28.55 and 47 respectively) than in the salt tolerant plants mixture $(92.59,19.72$ and 39.10 respectively). The mixture had higher ash and ether extract (EE) contents than Berseem hay since Atriplex nummularia is rich in ash fiber and EE (21.72 and 10.28, respectively.). Sorghum bicolor and Pearl millet contained lower crude protein (CP) (averaged 9\%) compared to Atriplex nummularia (12.07\%), therefore CP in the mixture forage was decreased to $10.91 \%$. However, it seems fair enough that $\mathrm{CP}$ of the mixture could cover the nitrogen requirements of grazing animals (El Shaer, 2003). These data agreed with those of Abdou et al. (2011). Also Fayed et al. (2010) reported that Berseem hay and Atriplex nummularia had similar CP concentrations (averaged 12\%). However, the CP of salt tolerant plant might be lower than those reported by other workers (Aganga et al., 2003) that could be attributed to different factors such as climate and stage of growth.

Table (1): Chemical composition (\%) of the individual feed stuffs and the mixture diet (on dry matter basis)

\begin{tabular}{|c|c|c|c|c|c|c|c|}
\hline & DM & OM & $\mathrm{CP}$ & $\mathrm{CF}$ & $\mathrm{EE}$ & NFE & Ash \\
\hline Berseem hay & 100.00 & 88.95 & 12.22 & 28.55 & 1.18 & 47.00 & 11.05 \\
\hline Atriplex nummularia & 94.27 & 78.27 & 12.07 & 20.15 & 10.28 & 35.78 & 21.72 \\
\hline Sorghum bicolor & 92.17 & 86.29 & 9.68 & 22.99 & 6.31 & 47.31 & 13.71 \\
\hline Pearl millet & 91.93 & 83.81 & 9.18 & 21.40 & 8.25 & 44.98 & 16.19 \\
\hline Salt tolerant mixture* & 92.59 & 83.41 & 10.91 & 19.72 & 13.68 & 39.10 & 16.59 \\
\hline CFM & 93.76 & 89.20 & 16.72 & 12.78 & 4.11 & 55.59 & 10.80 \\
\hline
\end{tabular}

\section{Live body weight changes:}

The results presented in Table (2) revealed that live body weight and body gain of control (fed berseem hay + CFM) and experimental (fed salt tolerant fodder crops mixture+ CFM) groups of Damascus doe goats were similar. These results also suggested that control diet of Damascus does can be replaced with salt tolerant fodder crops mixture (Atriplex nummularia, Sorghum bicolor and Pearl millet) without any adverse effects on live weights of the goats. This resulted in a significant financial benefit in feed costs and was possible because of the higher crude protein concentration in the atriplex. The results of study were in line with the findings of Shaker et al. $(2008,2014)$ and Shaker $(2014)$ who reported that feeding Barki lambs with mixture of salt tolerant fodder crops mixture resulted in non-significant differences in body weight with control group. These indicated the potentiality of such salt tolerant fodder mixture to fulfill the animal requirements to maintain their body weight. However, the presence of CFM is very important to achieve benefits from salt tolerant fodders. In this concern, Ben Salem et al. (2002) reported that supplementing cactus based diets with Atriplex nummularia foliage improved the feeding value of these diets and improved sheep growth. Goats find it difficult, physiologically, to cope with ingesting large amounts of salt, resulting in decreased feed intake. Consequently, they struggle to maintain weight when grazing saltbush without supplementation mainly because of its high salt content (Masters et al., 2005; Chadwick, 2009). Moreover, it was assumed that the insignificant body weight gain due to feeding saltbushes alone might be related to increased body water retention and accumulation of sodium (Nawaz et al., 1994; Masters et al., 2005). 
Table (2): Live body weight of Shami doe goats as affected by feeding salt tolerant fodder crops mixture

\begin{tabular}{|c|c|c|c|}
\hline Item & G1 & G2 & $\pm \mathrm{SE}$ \\
\hline Initial body weight (IBW)(kg) & $25.07^{\mathrm{a}}$ & $25.00^{\mathrm{a}}$ & \pm 2.44 \\
\hline Final body weight (FBW)(kg) & $30.43^{\mathrm{a}}$ & $31.00^{\mathrm{a}}$ & \pm 2.48 \\
\hline Bodyweight changes $(\mathrm{BWC})(\mathrm{kg})$ & $5.36^{\mathrm{a}}$ & $6.00^{\mathrm{a}}$ & \pm 0.39 \\
\hline Average daily gain $(\mathrm{ADG})(\mathrm{gm})$ & $35.71^{\mathrm{a}}$ & $40.00^{\mathrm{a}}$ & \pm 2.65 \\
\hline
\end{tabular}

\section{Blood metabolites:}

Blood metabolic profile (BMP) is a set of diagnostic procedures that are based on determining the various indicators in the blood of animals (Van Saun, 2000). Nutritional status and animal health can be assessed using BMP (Herdt et al., 2000). The most important factors affecting the concentration of blood metabolic indicators are nutrition and physiological status (Antunovic et al., 2002; Roubies et al., 2006).

\section{Total proteins profile:}

Table (3) shows the average values of total proteins profile of goat fed salt tolerant plants mixture during different physiological states. Goats fed salt tolerant shrubs mixture had slightly insignificant lower concentrations of total proteins (TP), albumin (AL), globulin (GL) and albumin/ globulin ratio (A/G ratio) as compared with control group. These results are in accordance with those obtained by Shaker et al. (2008, 2014) and Shaker (2014). Taking the chemical composition of feed mixture into consideration (Table 1), the slight decrease in total proteins fraction could be attributed to the lower crude protein recorded in ration of salt tolerant plants mixture. Shahen et al. (2004) found a positive correlation between dietary protein and plasma protein concentrations. From another point of view, the insignificant decrease of TP, Al, Gl and A/G ratio values in treated animals (G2) might be attributed to the high content of tannins in such salt tolerant plants where tannins were reported to decrease the digestibility of crude protein (Muller et al., 1989). Moreover, Coles (1986) found that poor absorption of dietary constituents from the intestinal tract leads to hypoproteinemia. At the same time, higher salt intake might be another reason (Weeth and Haverland, 1961). In accordance, Tata and Widnell (1966) observed a decrease in total protein concentration due to drinking saline water which might possibly reduce hepatic synthesis of RNA which in turn depressed the incorporation of amino acids for protein synthesis.

Analyzing the data revealed the significant effect of pregnancy on total proteins profile. According to the physiological status, the mean values of TP, AL and GL decreased significantly $(\mathrm{P}<0.05)$ with advancing gestation period where the lowest concentrations were observed in late gestation period. Karapehlivan et al. (2007) stated that TP is one of the important blood indicators for metabolic activity in pregnant animals. Balikci et al. (2007) and Gürgöze et al. (2009) reported a decrease in TP on day 120 to 150 of gestation in ewes compared to other stages of gestation. In accordance, El-Sherif and Assad (2001) and Taghipour et al. (2010) reported that TP gradually decreased during pre-partum period and reached the lowest level at parturition and then slowly increased afterward. This decrease might be due to the preparation of reproductive system during pregnancy (growth of uterus) which requires large quantity of protein (Vihan and Rai, 1983). During pregnancy, the rise in the mother's basal metabolic rate and the increase in nutrient requirement of placenta and fetus growth are involved in energy and protein consumption, consequently, dam blood serum chemistry values were decreased (Safsaf et al., 2012). Relative to protein metabolism, the decline in serum protein is associated to the fact that the fetus synthesizes its proteins from the amino acids provided by the mother and growth of fetus enhances exponentially reaching maximum levels during late pregnancy, particularly in the muscles (Jainudeen and Hafez, 1994; Antunovic et al. 2002).

The level of albumin reflects the storage capacity of the total protein (Louacini et al., 2012) and it is a very important source of amino acids for the necessities of the fetus and the mother (Jainudeen and Hafez, 1989). According to Piccione et al. (2009) and Kaneko et al. (2008), the noticeable progressive decrease of albumin during the second half of pregnancy is due to the increase of nutrient transfer toward the mammary gland and growing fetus. Similar decreasing trend were also recorded for globulin (Antunovic et al., 2011; Bamerny, 2013) which might be due a rapid extraction of immunoglobulin (Ig) from the plasma during the last few months of pregnancy when a colostrum is being formed in the mammary gland as a preparatory step for the bulk secretion of Ig into colostrum after lambing (El-Sherif and Assad, 2001; Karapehlivan et al., 2007; Kaneko et al., 2008). Globulin can be also used for the formation of milk 
protein (casein) as suggested by Sharma et al. (2015) which might explain the decreased level of total protein reported in the current study.

\section{Some energy metabolism indicators:}

\section{A: Plasma Glucose:}

The obtained results in Table (4) demonstrated that animals fed salt tolerant plants mixture showed a significant $(\mathrm{P}<0.01)$ decrease in glucose concentration as compared to the control animals. Similar results were reported by Shaker et al. $(2008,2014)$ and Shaker (2014) who attributed the reduction in glucose concentration to the high content of tannins in these salt tolerant plants. Tannins were reported to adversely influence digestibility and absorption of nutrients such as proteins and amino acids, carbohydrates and lipids and also the activity of digestive enzymes (Ortiz et al., 1993) through inhibiting digestive enzymes and/or by altering permeability of the gut wall (Streeter et al., 1993). High salt content in the salt tolerant plants mixture used in this experiment might be another reason for such reduction in glucose concentration. Assad and El-Sherif (2002) studied the effect of saline water on sheep and they found an incidence of energy expenditure by sheep for coping with saline load, which exerted a stress on the liver function. It could be concluded that due to the lower values of glucose in blood of doe goats fed salt tolerant plants mixture they must be supplied by energy-rich diets.

Table (3): Total proteins profile of Shami doe goats as affected by feeding salt tolerant fodder crops mixture

\begin{tabular}{|c|c|c|c|c|c|c|c|c|c|}
\hline \multirow{2}{*}{ Item } & \multirow{2}{*}{ Treatment } & \multicolumn{4}{|c|}{ Pregnancy stages } & \multirow{2}{*}{ Overall } & \multicolumn{3}{|c|}{$+\mathrm{SE}$} \\
\hline & & Dry & Early & Mid & Late & & $\mathrm{T}$ & $\overline{\mathrm{S}}$ & TxS \\
\hline Total & G1 & $7.25^{\mathrm{a}}$ & $8.13^{\mathrm{a}}$ & $7.19^{\mathrm{a}}$ & $5.81^{\mathrm{ab}}$ & $7.10^{\mathrm{A}}$ & \multirow{3}{*}{$0.39^{\mathrm{NS}}$} & \multirow{3}{*}{$0.56^{*}$} & \multirow{3}{*}{$0.79^{*}$} \\
\hline \multirow{2}{*}{$\begin{array}{l}\text { proteins } \\
(\mathrm{g} / \mathrm{l})\end{array}$} & $\mathrm{G} 2$ & $5.98^{\mathrm{ab}}$ & $8.26^{\mathrm{a}}$ & $6.72^{\mathrm{ab}}$ & $4.14^{\mathrm{b}}$ & $6.28^{\mathrm{A}}$ & & & \\
\hline & Overall & $6.61^{\mathrm{AB}}$ & $8.19^{\mathrm{A}}$ & $6.95^{\mathrm{A}}$ & $4.97^{\mathrm{B}}$ & & & & \\
\hline \multirow{3}{*}{$\begin{array}{l}\text { Albumin } \\
(\mathrm{g} / \mathrm{l})\end{array}$} & G1 & $2.64^{\mathrm{ab}}$ & $3.37^{\mathrm{a}}$ & $3.33^{\mathrm{a}}$ & $2.90^{\mathrm{ab}}$ & $3.06^{\mathrm{A}}$ & \multirow{3}{*}{$0.16^{\mathrm{NS}}$} & \multirow{3}{*}{$0.22^{*}$} & \multirow[t]{3}{*}{$0.32^{*}$} \\
\hline & $\mathrm{G} 2$ & $3.34^{\mathrm{a}}$ & $3.39^{\mathrm{a}}$ & $2.15^{\mathrm{b}}$ & $1.92^{\mathrm{b}}$ & $2.70^{\mathrm{A}}$ & & & \\
\hline & Overall & $2.99^{\mathrm{AB}}$ & $3.38^{\mathrm{A}}$ & $2.74^{\mathrm{AB}}$ & $2.41^{\mathrm{B}}$ & & & & \\
\hline \multirow{3}{*}{$\begin{array}{c}\text { Globulin } \\
(\mathrm{g} / \mathrm{l})\end{array}$} & G1 & 4.61 & 4.76 & 3.86 & 2.91 & $4.04^{\mathrm{A}}$ & \multirow[t]{3}{*}{$0.30^{\mathrm{NS}}$} & \multirow[t]{3}{*}{$0.43^{*}$} & \multirow[t]{3}{*}{$0.61^{\mathrm{NS}}$} \\
\hline & $\mathrm{G} 2$ & 2.64 & 4.87 & 4.57 & 2.22 & $3.57^{\mathrm{A}}$ & & & \\
\hline & Overall & $3.62^{\mathrm{AB}}$ & $4.81^{\mathrm{A}}$ & $4.21^{\mathrm{A}}$ & $2.56^{\mathrm{B}}$ & & & & \\
\hline \multirow{3}{*}{$\begin{array}{l}\mathrm{A} / \mathrm{G} \\
\text { ratio }\end{array}$} & G1 & $0.61^{\mathrm{ab}}$ & $0.87^{\mathrm{ab}}$ & $1.09^{\mathrm{ab}}$ & $1.04^{\mathrm{ab}}$ & $0.91^{\mathrm{A}}$ & \multirow{3}{*}{$0.09^{\mathrm{NS}}$} & \multirow{3}{*}{$0.13^{\mathrm{NS}}$} & \multirow{3}{*}{$0.18^{*}$} \\
\hline & G2 & $1.35^{\mathrm{a}}$ & $0.71^{\mathrm{ab}}$ & $0.47^{\mathrm{b}}$ & $0.90^{\mathrm{ab}}$ & $0.85^{\mathrm{A}}$ & & & \\
\hline & Overall & $0.98^{\mathrm{A}}$ & $0.79^{\mathrm{A}}$ & $0.78^{\mathrm{A}}$ & $0.97^{\mathrm{A}}$ & & & & \\
\hline
\end{tabular}

$T=$ treatment; $S=$ pregnancy stage; $G 1=$ animals fed berseem hay; G2 = animals fed salt tolerant fodder mixture, * = $P<0.05 ; N S=$ not significant; $a, b=$ values in the same rows within the same parameter with the same superscript are not differ significantly; $A, B=$ values in the same column with the same superscript are not differ significantly

Statistical analysis (Table 4) revealed that glucose level was not affected by pregnancy stage. Moreover, there were no differences in glucose level between dry and pregnant doe goats. The significant decrease in insulin (Table 4) during pregnancy seemed to play a role in keeping glucose levels. The low observed glucose levels in mid pregnancy might be associated with fetus development and mobilization of maternal glucose to fetal blood circulation as illustrated by Jacob and Vadodaria (2001). On the other hand, the significant interaction between treatment and physiological stage was due to the lower level of plasma glucose in animals of G2 than those of G1 all over the experimental period by $14.58 \mathrm{mg} / \mathrm{dl}$ in average, while was only $11.75 \mathrm{mg} / \mathrm{dl}$ at early stage but reached $15.83 \mathrm{mg} / \mathrm{dl}$ at late stage. Glucose was stated to be needed in higher levels during pregnancy due to high consumption by fetus and milk formation (Firat and Ozpinar, 2002; Ramin et al., 2007). The present results emphasize that the fodder mixture did not cover the high need of energy, which necessitate supplementation with energy-rich diet especially at mid and late pregnancy. On contrary, some authors reported different findings of blood glucose level. Al-Dewachi (1999) reported high blood glucose levels in pregnant ewes.

\section{B: Insulin}

Metabolic hormones such as insulin play an important role in animal metabolism. Insulin is a 5.8-kDa protein synthesized in the pancreatic $\beta$-cells and secreted in response to plasma glucose level (Magistrelli et al., 2008). Insulin has an important role in glucose transport and modulates peripheral satiety signals and directly targets the central nervous system to inhibit food intake (Gale et al., 2004). Also, insulin has 
an important role in lipid metabolism, stimulating lipogenesis and inhibiting lipolysis (Ban-Tokuda et al., 2008). The present data revealed that insulin level was significantly increased $(\mathrm{P}<0.01)$ in animals fed salt tolerant forages (G2) in comparison to their counterparts of control group (Table 4). In this context, Atriplex farinose was reported to exert hypoglycemic activity through insulin release stimulatory effect (Soliman and Donia, 2015). The maximum reduction in glucose levels was observed in rats receiving 400 $\mathrm{mg} / \mathrm{kg}$ of Atriplex farinose extract. This supported by the present data of the reduced glucose concentration in animals fed salt tolerant plants mixture. The most reasonable explanation to rising insulin in G2 was given by Ogihara et al. (2001) and Donovan et al. (1993) that high-salt diets might be a factor in promoting insulin resistance as a normal physiological response to dietary salt loading. It has been reported that insulin resistance is coupled with increased insulin secretion, due to homeostatic mechanisms compensating the insensitivity (Isganaitis and Lusting, 2005), thus resulting in higher concentrations of insulin.

Taking the physiological status into consideration, the levels of insulin during gestation periods were significantly lower than that of dry period (Table 4). The lowest value was observed in mid gestation period. This result was in accordance with those reported by Antunovic et al. (2011), who suggested that the physiological status had significant effect on the serum concentration of insulin. Digby et al. (2008) found that high salt feeding during pregnancy is associated with changes in the circulating concentrations of insulin in the pregnant ewe. Changes in biochemical indicators and the concentration of insulin pointed at the energy deficit of ewes in pregnancy. Therefore, Antunovic et al. (2011) recommended the importance of measuring blood metabolic profile and insulin hormone to assess the nutritional and health status of pregnant and lactating ewes. The significant interaction between treatment and physiological stage for insulin level was for the reverse effect of each source of variance. While insulin increased by feeding salt tolerant plants, it decreased by advancing pregnancy stage. The fall in insulin level is associated with a concomitant decrease in the insulin receptors of the adipocytes which is responsible for fat mobilization during mid pregnancy (Vernon et al., 1981). As reported earlier by Khan and Ludri (2002) and Mondal et al. (2014), the decline in plasma insulin concentration around parturition could facilitate the mobilization of nutrients from fat depot for milk synthesis. The decrease in insulin levels during mid pregnancy may be attributed to sharp increase in non-esterified fatty acid (NEFA) concentrations and decrease in glucose concentrations (Bauman and Currie, 1980).

\section{C: Cholesterol}

Animals fed salt tolerant plants mixture had insignificant lower cholesterol concentration as compared with the control ones (Table 4). Similar results were reported by Shaker et al. (2008) in Barki lambs and Fayed (2009) in Barki rams. This insignificant decrease in cholesterol levels might be owing to saponins contents (Fayed et al., 2010; Ben Salem et al., 2010). This is consistent with those reported by Potter et al. (1993) who found that saponins from different sources causing lower serum cholesterol levels in a variety of animals. The explanation was given by Han et al. (2000) and Francis et al. (2002) that several dietary saponins have a hypocholesterolaemic action through inhibiting the cholesterol absorption causing reduction in plasma high-density lipoprotein cholesterol fraction and/or delaying the intestinal absorption of dietary fat by inhibiting pancreatic lipase activity. On the other hand, the anti-nutritional factors were found to affect lipids profile indirectly where tannins play a considerable role in lipids digestibility by complexing with fatty acids (Romero et al., 2000) causing a decrease in cholesterol absorption and increase in fat excretion (Bravo et al., 1993). Similarly, Ayyat et al. (1991) noted a decrease in cholesterol level as a result of high salt intake. These authors suggested that protein and fat metabolism were negatively affected as a result of drinking saline water.

Cholesterol level showed insignificant gradual increase from dry period to late gestation (Table 4). Being a metabolic parameter, cholesterol is used to detect health problems that might be encountered during pregnancy and to assess the nutritional status of animals (Firat and Ozpinar, 1996). Insignificant increased cholesterol level in blood of different animal species during gestation period especially at late stage had been detected by Waziri et al. (2010) and Antunovic et al. (2011). In sheep, during late pregnancy, blood serum lipids profile was found to be characterized by increased concentration of total cholesterol, triglycerides and lipoproteins (Schlumbohm et al., 1997) due to an increased mobilization of fatty acids from adipose tissue making available new sources for foetal growth. It was suggested that if ewes do not receive at least half of the required energy during late pregnancy, fat depots are mobilized in large quantities (Firat and Ozpinar, 2002). Variation in blood cholesterol content has been observed during oestrus and pregnancy, as precursor of the steroid hormones (Iriadam, 2007) and this increase might be due to estrogen stimulation during the pregnancy (Kaushik and Bugalia, 1999).

Furthermore, Khatun et al. (2011) reported that with the advancement of pregnancy, serum cholesterol level showed a decreasing trend. Taghipour et al. (2010) reported that serum cholesterol and triglyceride 
concentrations gradually decreased during pregnancy and reached low levels after lambing. Several studies have demonstrated the impact of factors such as breed (Abdelrahmen and Aljumaah, 2012), season (Antunovic et al., 2002), feed, age and experimental conditions on the changes in blood biochemical parameters (Boudebza et al., 2014). All these factors could explain the differences observed between our results and those reported by other authors.

\section{Liver enzymes (AST, ALT and ALP):}

Feeding salt tolerant plants mixture resulted in a significant $(\mathrm{P}<0.01)$ increase in both ALT and ALP enzymes but insignificant increase in AST enzyme activity (Table 4). These results were in harmony with those of Shaker (2014) on sheep and Shaker et al. (2014) and Donia et al. (2014) on goats. They found that the activities of liver enzymes were higher $(\mathrm{P}<0.01)$ in animals fed salt tolerant plants comparing to control group. This increment of liver enzyme activities might be attributed to high tannins content in these salt tolerant plants mixture (Tripathy et al., 1984) or to high content of salt as reported by Hussein (1987) on sheep and Ibrahim (1995) on goats. Similarly, Assad and El-Sherif (2002) in their study on sheep, found that ALT and AST activities were increased significantly as a result of drinking saline water.

The effects of pregnancy on liver enzyme (AST and ALT) showed fluctuation in their mean values (Table 4). The data showed insignificant decreased in AST while the decrease in ALT was significant $(\mathrm{P}<0.05)$ and the lowest values was recorded during mid-gestation period. The mean values of ALP showed the same trend of ALT enzyme where values of ALP showed significant $(\mathrm{P}<0.01)$ decrease in mid and late gestation periods and the lowest values was recorded during mid-gestation. The significant interaction between treatment and physiological stage for ALP was for the reverse effect of each source of variance. While ALP increased by feeding salt tolerant plants, it decreased by advancing pregnancy stage.

Metabolic profiles have been used to predict prepartum and postpartum metabolic problems and for the diagnosis of metabolic disorders and the assessment of the nutritional status of animals. The study of biochemical profiles in maternal serum is a tool for pregnancy diagnosis and certain changes in values of liver function tests occur during normal pregnancy and serum liver function tests are essential in the management of liver diseases during pregnancy (Gürgöze et al., 2009). The subnormal or elevated enzyme level in serum is one of the important tools to assess liver functioning and healthy state of pregnancy (Khatun et al., 2011). It has been reported that the transaminase enzymes play a significant role in the normal continuation of gestation (Hafez et al., 1983). Serum ALT activity showed a tendency to decrease in late gestation in the Angora cat in the study of Simsek et al. (2015), it was ascertained that serum ALT activity had decreased on day 55 of gestation, in comparison to the value measured on day 15 of gestation. In the present study, it is worth to mention that the insignificant differences observed for AST among experimental stages and the significant decreased of ALT and ALP recorded during mid and late pregnancy of Shami goats might indicate that animals were in good health and didn't suffer from pregnancy toxaemia. Major adaptations in maternal physiology and metabolism are required for successful pregnancy outcome. As gestation progresses, reference ranges for the concentration of many biochemical parameters change significantly from those found in the non-pregnant state (Lockitch, 1997).

Data available for the impact of gestation on ALT and AST activity are unclear and are somewhat controversial (Gürgöze et al., 2009). In a few studies, a decrease in AST and ALT activities has been reported by Manish-Mahawar et al. (2004). Also, In agreement, Khatun et al. (2011) reported that serum AST and ALT levels decreased significantly with advancing pregnancy. While some researchers determined adverse results, El-Sherif and Assad (2001) reported that during pregnancy AST and ALT in pregnant Barki ewes started to increase significantly reaching maximum values at parturition.

\section{Kidney function indicators:}

\section{A: Urea and Creatinine}

Urea and creatinine are the two main nitrogenous compounds eventually excreted by kidney and their level in serum is known to reflect the state of glomerular filtration rate and kidney function (Kaneko, 1989). Accordingly, any change of their concentration means impaired glomerular filtration and/or insufficiency of renal tubules (Kaneko, 1989).

The present results (Table 5) revealed that urea and creatinine behaved the same trend. Feeding a mixture of salt tolerant plants significantly decreased $(\mathrm{P}<0.01)$ the concentrations of urea and creatinine in comparison with control diet. This reduction could be owing to the presence of tannins, which reduce the ruminal proteins degradation (Mashudi et al., 1997). Moreover, Clark and Clark (1978) reported that feeding on Atriplex species caused destruction of renal nephrons since such plants contain high amounts 
of oxalates. Cheeke (1995) reported that the common effect of oxalate is to cause kidney damage owing to blocking of tubules by crystals of calcium oxalate. This does not necessarily cause death, but the kidney damage remains and subsequently ingestion of oxalate-containing plants may have fatal results. These results were in agreement with those of Shaker et al. (2014) and Donia et al. (2014) on goats. Conversely, some studies showed no adverse effect of salt plant on kidney function. Al-Khalasi et al. (2010) reported that there were no significant differences in blood urea of Omani sheep fed salt-tolerant sorghum forage or Rhodes grass and El-Bassiony (2013) reported that feeding salt tolerant plants did not have any adverse effects on BUN concentration. In the current study, urea and creatinine concentrations were increased insignificantly throughout the gestation period (Table 5). Similar results for urea and creatinine were reported by Donia et al. (2014) on goats and by Saeed et al. (2009) on pregnant camels. However, these indices might vary depending on factors such as sex, age, weather, stress, season and physical exercise (Kaneko et al., 2008). Mufti et al. (2000) reported that as the gestation age advanced, marked changes occur in urea and creatinine in amniotic and maternal serum in ewes. The increased level of urea during pregnancy might be related to either nutritional management or high protein metabolism (Gürgöze et al., 2009). The high requirement for energy by pregnant sheep during their second half of pregnancy led to an increase in urea level (Piccione et al., 2009). These results coincided with the decreased protein concentration in the current study.

Table (4): Energy metabolism blood indicators and liver enzymes of Shami doe goats as affected by feeding salt tolerant fodder crops mixture and stage of pregnancy

\begin{tabular}{|c|c|c|c|c|c|c|c|c|c|}
\hline \multirow{2}{*}{ Item } & \multirow{2}{*}{$\begin{array}{c}\text { Treatme } \\
\mathrm{nt}\end{array}$} & \multicolumn{4}{|c|}{ Pregnancy stage } & \multirow{2}{*}{ Overall } & \multicolumn{3}{|c|}{$\pm \mathrm{SE}$} \\
\hline & & \multicolumn{2}{|c|}{ Dry } & Early & Late & & $\mathrm{T}$ & $\mathrm{S}$ & $\mathrm{TxS}$ \\
\hline \multirow{3}{*}{$\begin{array}{l}\text { Glucose } \\
\text { (mg/l) }\end{array}$} & G1 & $53.25^{\mathrm{a}}$ & $49.39^{\mathrm{ab}}$ & $48.55^{\mathrm{ab}}$ & $53.37^{\mathrm{a}}$ & $51.14^{\mathrm{A}}$ & \multirow{3}{*}{$2.69^{* * *}$} & \multirow{3}{*}{$3.80^{\mathrm{NS}}$} & \multirow{3}{*}{$5.37^{*}$} \\
\hline & G2 & $36.80^{\mathrm{ab}}$ & $37.64^{\mathrm{ab}}$ & $34.26^{\mathrm{b}}$ & $37.54^{\mathrm{ab}}$ & $36.56^{\mathrm{B}}$ & & & \\
\hline & Overall & 45.03 & 43.52 & 41.41 & 45.46 & & & & \\
\hline \multirow{3}{*}{$\begin{array}{l}\text { Insulin } \\
(\mu \mathrm{U} / \mathrm{ml})\end{array}$} & G1 & $22.76^{\mathrm{b}}$ & $3.46^{\text {ed }}$ & $0.77^{\mathrm{f}}$ & $2.49^{\mathrm{e}}$ & $7.37^{\mathrm{B}}$ & \multirow{3}{*}{$0.18^{* * *}$} & \multirow{3}{*}{$0.26^{* *}$} & \multirow{3}{*}{$0.37^{* *}$} \\
\hline & G2 & $25.52^{\mathrm{a}}$ & $2.86^{\mathrm{de}}$ & $4.23^{\mathrm{d}}$ & $5.81^{\mathrm{c}}$ & & & & \\
\hline & Overall & $24.14^{\mathrm{A}}$ & $3.16^{\mathrm{C}}$ & $2.50^{\mathrm{D}}$ & $4.15^{\mathrm{B}}$ & & & & \\
\hline \multirow{3}{*}{$\begin{array}{l}\mathrm{CHO} \\
(\mathrm{mg} / \mathrm{dl})\end{array}$} & G1 & 96.43 & 97.12 & 99.00 & 103.47 & $99.01^{\mathrm{A}}$ & \multirow{3}{*}{$2.34^{\mathrm{NS}}$} & \multirow{3}{*}{$3.32^{\mathrm{NS}}$} & \multirow{3}{*}{$4.69^{\mathrm{NS}}$} \\
\hline & G2 & 92.32 & 92.47 & 93.45 & 96.32 & $93.64^{\mathrm{A}}$ & & & \\
\hline & Overall & 94.37 & 94.79 & 96.22 & 99.90 & & & & \\
\hline \multirow{3}{*}{$\begin{array}{l}\text { AST } \\
\text { (IU/l) }\end{array}$} & G1 & 21.48 & 24.60 & 20.28 & 23.40 & $22.44^{\mathrm{A}}$ & \multirow{3}{*}{$1.43^{\mathrm{NS}}$} & \multirow{3}{*}{$2.03^{\mathrm{NS}}$} & \multirow{3}{*}{$2.87^{\mathrm{NS}}$} \\
\hline & $\mathrm{G} 2$ & 26.76 & 24.12 & 21.72 & 31.32 & $25.98^{\mathrm{A}}$ & & & \\
\hline & Overall & 24.12 & 24.36 & 21.00 & 27.36 & & & & \\
\hline \multirow{2}{*}{$\begin{array}{l}\text { ALT } \\
\text { (IU/l) }\end{array}$} & G1 & $\begin{array}{l}29.66 \\
36.44\end{array}$ & $\begin{array}{l}29.20 \\
35.30\end{array}$ & $\begin{array}{l}26.47 \\
29.32 S\end{array}$ & 29.83 & $\begin{array}{r}28.79^{\mathrm{B}} \\
33.07^{\mathrm{A}}\end{array}$ & \multirow[t]{2}{*}{$0.86^{* *}$} & \multirow[t]{2}{*}{$1.21^{*}$} & \multirow[t]{2}{*}{$1.72^{\mathrm{NS}}$} \\
\hline & $\begin{array}{l}\text { U2 } \\
\text { Overall }\end{array}$ & $\begin{array}{c}36.44 \\
33.05^{\mathrm{A}}\end{array}$ & $\begin{array}{c}35.30 \\
32.25^{\mathrm{A}}\end{array}$ & $\begin{array}{l}29.32 \mathrm{~S} \\
27.89^{\mathrm{B}}\end{array}$ & $\begin{array}{c}31.21 \\
30.52^{\mathrm{AB}}\end{array}$ & & & & \\
\hline \multirow{3}{*}{$\begin{array}{l}\text { ALP } \\
\text { (IU/l) }\end{array}$} & G1 & $189.15^{\mathrm{b}}$ & $187.14^{\mathrm{b}}$ & $134.26^{\mathrm{e}}$ & $151.24^{\mathrm{d}}$ & $165.45^{\mathrm{B}}$ & \multirow{3}{*}{$2.82^{* * *}$} & \multirow{3}{*}{$3.99^{* *}$} & \multirow{3}{*}{$5.65^{* *}$} \\
\hline & G2 & $209.65^{\mathrm{a}}$ & $213.62^{a}$ & $164.71^{\mathrm{cd}}$ & $177.14^{\mathrm{bc}}$ & $191.28^{\mathrm{A}}$ & & & \\
\hline & Overall & $199.40^{\mathrm{A}}$ & $200.38^{\mathrm{A}}$ & $149.48^{\mathrm{C}}$ & $164.19^{\mathrm{B}}$ & & & & \\
\hline
\end{tabular}

$T=$ treatment $S=$ pregnancy stage $; G 1=$ animals fed berseem hay; $G 2=$ animals fed salt tolerant fodder mixture, $*=$ $P<0.05 ; * *=P<0.01 ; N S=$ not significant; $a, b=$ values in the same rows within the same parameter with the same superscript are not differ significantly; $A, B=$ values in the same column with the same superscript are not differ significantly

The obtained data revealed insignificant increased mean values of creatinine in pregnant goats to reach its peak during late pregnancy (Table 5). In agreement, Khatun et al. (2011) reported that creatinine showed in general an increasing trend in ewe's serum during different stages of pregnancy. Abu El-Ella and Kommonna (2013) on Damascus goats and Abdel-Hafez (2002) on sheep reported that serum creatinine concentration was increased gradually with advancing pregnancy. The increment in creatinine during this period might be owing to foetus development (Korshom et al., 1993). Moreover, Piccione et al. (2009) reported that the creatinine level was affected by the physiological phase and showed the higher levels during the late pregnancy and early lactation. It is recognized that during the late gestation, the mother, for the foetal maternal circulation, undergo the load of organic waste of the fetus (Ferrell, 
1991). So, the increase in serum creatinine levels could be attributed to the development of the foetal musculature, which is well documented in sheep and ewes too (Roubies et al., 2006).

\section{B: Sodium and Potassium}

Minerals occur in body fluids and tissues as electrolytes, concerned with the maintenance of osmotic pressure, acid-base balance, membrane permeability and tissue irritability (Underwood and Suttle, 1999). In the current study, plasma sodium $(\mathrm{Na})$ values were higher $(\mathrm{P}<0.01)$ in animals fed salt tolerant forages (G2) than in those fed traditional diet (Table 5). Similar results were obtained by Nasr et al. (2002); Shaker et al. (2008) and Shaker (2014) who reported that serum $\mathrm{Na}^{+}$levels was increased significantly in animals fed salt tolerant plant. This increase might be due to high content of sodium $(6.45 \%)$ and chloride (7.03\%) in atriplex as reported by Mohamed (1996). Wichell (1976) noted a relationship between plasma $\mathrm{Na}^{+}$and its intake; which is already high in such forages. The current results also indicate that the concentration of $\mathrm{Na}$ was affected significantly $(\mathrm{P}<0.01)$ by physiological status where it increased gradually from dry to mid-gestation period and then a slight regression was observed at late pregnancy specially in animals of G2 (Table 5). Pregnancy constituted metabolic stress, associated with alterations in the minerals profile dependent on the reproductive status of small ruminants. Metabolism of mineral elements plays a significant role in the regulation of physiological functions of pregnancy. The concentration of minerals varies in blood of animals as a result of changes in the concentration of nutrients in the diet and interactions between those nutrients, transfer of nutrients to the fetus, initiation of milk synthesis, changes in hormone levels and body weight loss (Kincaid, 2008).

Table (5): Changes in kidney function indicators of Shami doe goats as affected by feeding salt tolerant fodder crops mixture during pregnancy

\begin{tabular}{|c|c|c|c|c|c|c|c|c|c|}
\hline \multirow{2}{*}{ Item } & \multirow{2}{*}{ Tr. } & \multirow{2}{*}{ Dry } & \multicolumn{3}{|c|}{ Pregnancy periods } & \multirow{2}{*}{ Overall } & \multicolumn{3}{|c|}{$\pm \mathrm{SE}$} \\
\hline & & & Early & Mid & Late & & $\mathrm{T}$ & $\mathrm{S}$ & $\mathrm{TxS}$ \\
\hline \multirow{3}{*}{$\begin{array}{l}\text { Urea } \\
(\mathrm{mg} / \mathrm{dl})\end{array}$} & G1 & $42.57^{\mathrm{abc}}$ & $43.27^{\mathrm{abc}}$ & $46.24^{\mathrm{ab}}$ & $47.04^{\mathrm{a}}$ & $44.78^{\mathrm{A}}$ & \multirow{3}{*}{$1.58^{* *}$} & \multirow{3}{*}{$2.24^{\mathrm{NS}}$} & \multirow{3}{*}{$3.17^{*}$} \\
\hline & $\mathrm{G} 2$ & $37.27^{\mathrm{bc}}$ & $35.51^{\mathrm{c}}$ & $39.36^{\mathrm{abc}}$ & $38.36^{\mathrm{abc}}$ & $37.63^{\mathrm{B}}$ & & & \\
\hline & Overall & 39.92 & 39.39 & 42.80 & 42.70 & & & & \\
\hline \multirow{3}{*}{$\begin{array}{l}\text { Creat. } \\
(\mathrm{mg} / \mathrm{dl})\end{array}$} & G1 & $1.14^{\mathrm{ab}}$ & $1.21^{\mathrm{ab}}$ & $1.29^{\mathrm{a}}$ & $1.31^{\mathrm{a}}$ & $1.24^{\mathrm{A}}$ & \multirow{3}{*}{$0.04^{* *}$} & \multirow{3}{*}{$0.06^{\mathrm{NS}}$} & \multirow{3}{*}{$0.08^{*}$} \\
\hline & $\mathrm{G} 2$ & $0.88^{c}$ & $0.97^{\mathrm{bc}}$ & $1.00^{\mathrm{bc}}$ & $1.07^{\mathrm{abc}}$ & $0.98^{\mathrm{B}}$ & & & \\
\hline & Overall & 1.01 & 1.09 & 1.14 & 1.19 & & & & \\
\hline \multirow{3}{*}{$\begin{array}{c}\mathrm{Na} \\
(\mathrm{ppm})\end{array}$} & G1 & $3500^{\mathrm{f}}$ & $6400^{c}$ & $6500 b^{c}$ & $6800^{\mathrm{a}}$ & $5800^{\mathrm{B}}$ & \multirow[t]{3}{*}{$14.43^{* *}$} & \multirow[t]{3}{*}{$20.41^{* *}$} & \multirow[t]{3}{*}{$28.86^{* *}$} \\
\hline & $\mathrm{G} 2$ & $3900^{\mathrm{e}}$ & $6600^{\mathrm{b}}$ & $6800^{\mathrm{a}}$ & $6200^{d}$ & $5875^{\mathrm{A}}$ & & & \\
\hline & Overall & $3700^{\mathrm{C}}$ & $6500^{\mathrm{B}}$ & $6650^{\mathrm{A}}$ & $6500^{\mathrm{B}}$ & & & & \\
\hline \multirow{3}{*}{$\begin{array}{c}\mathrm{K} \\
(\mathrm{ppm})\end{array}$} & G1 & $160^{\mathrm{bc}}$ & $170^{\mathrm{b}}$ & $159.66^{\mathrm{bc}}$ & $150^{\mathrm{cd}}$ & 159.92 & \multirow[t]{3}{*}{$2.27^{\mathrm{NS}}$} & \multirow[t]{3}{*}{$3.22^{* *}$} & \multirow[t]{3}{*}{$4.55^{* *}$} \\
\hline & $\mathrm{G} 2$ & $141^{\mathrm{d}}$ & $170^{\mathrm{b}}$ & $196^{\mathrm{a}}$ & $150.66^{\mathrm{cd}}$ & 164.41 & & & \\
\hline & Overall & $150.5^{\mathrm{B}}$ & $170^{\mathrm{A}}$ & $177.83^{\mathrm{A}}$ & $150.3^{\mathrm{B}}$ & & & & \\
\hline \multirow{3}{*}{$\begin{array}{l}\text { Aldo. } \\
\text { (pg/ ml) }\end{array}$} & G1 & $924.42^{\mathrm{a}}$ & $296.79^{c}$ & $370.39^{c}$ & $539.16^{\mathrm{b}}$ & $532.69^{\mathrm{A}}$ & \multirow[t]{3}{*}{$7.93^{* *}$} & \multirow[t]{3}{*}{$11.21^{* *}$} & \multirow[t]{3}{*}{$15.86^{* *}$} \\
\hline & $\mathrm{G} 2$ & $860.46^{\mathrm{a}}$ & $92.37^{\mathrm{d}}$ & $55.55^{\mathrm{d}}$ & $709.30^{\mathrm{b}}$ & $429.42^{\mathrm{B}}$ & & & \\
\hline & Overall & $892.4^{\mathrm{A}}$ & $194.6^{\mathrm{D}}$ & $213.0^{\mathrm{C}}$ & $624.2^{\mathrm{B}}$ & & & & \\
\hline $\begin{array}{l}T=\text { treatn } \\
P<0.05 ; \\
\text { superscri } \\
\text { sionifican }\end{array}$ & $n t ; S=p r t$ & ancy stag & $G 1=a n i$ & s fed bers & hay; $G 2=$ & lo fod & oler & dor & $\begin{array}{c}*= \\
\text { same } \\
\text { liffer }\end{array}$ \\
\hline
\end{tabular}

In the present study, the pattern of changes in $\mathrm{Na}$ might be due to the increase in salt demand for pregnancy and lactation. For goats, the $\mathrm{Na}$ requirements increased from $0.015 \mathrm{~g} / \mathrm{day}$ for dry animals to $0.034 \mathrm{~g}$ /day on 105-133 days of pregnancy (NRC, 2007). When sodium losses and sodium requirements for growth, pregnancy, lactation and work exceed intake, sodium deficiency can occur (Michell, 1985). This reduction may partly be related to the increase in foetal demands (Elnageeb and Abdelatif, 2010) or is most likely a consequence of loss of $\mathrm{Na}$ element in colostrum and milk. In mammals, the aqueous phase of colostrum contains high concentrations of the main ions ( $\mathrm{Na}$ and $\mathrm{Cl}$ ) (Ruchebusch et al., 1991). These results agreed with some studies which reported the decreased value of Na concentration mostly in parturition (Azab and Abdel-Maksoud, 1999; Ahmed et al., 2000; Donia et al., 2014).

The present results revealed that animals fed salt tolerant plants mixture had insignificant increase in plasma $\mathrm{K}$ values than their counterparts fed traditional diet (Table 5). In agreement, Shaker et al, (2008) 


\begin{abstract}
Amer
reported that animals fed on atriplex had higher $\mathrm{K}^{+}$concentration. According to physiological status, the mean values of potassium $\left(\mathrm{K}^{+}\right)$concentration was increased significantly from dry to reach peak during mid-gestation then declined again during late gestation compared to control diet (Table 5). Moreover, $\mathrm{K}^{+}$ concentrations in animals fed salt tolerant plants behaved the same trend of Na during gestation periods. To similar results had come by Azab and Abdel-Maksoud (1999), who reported that concentration of $\mathrm{K}^{+}$ was decreased during late pregnancy. Kulcu and Yur (2003) reported that there were significant differences between dry and pregnancy periods for serum $\mathrm{K}^{+}$concentration in sheep. These differences could be associated with increased requirements for intensive growth of fetus in high pregnancy due to increased synthesis of milk in lactation (Antunovic et al., 2011). Elnageeb and Abdelatif (2010) reported that $\mathrm{K}^{+}$level was decreased significantly $(\mathrm{P}<0.05)$ during late gestation.
\end{abstract}

\title{
C: Aldosterone
}

The pregnant goats fed salt tolerant forages $(\mathrm{G} 2)$ had significant lower $(\mathrm{P}<0.01)$ value of aldosterone than pregnant goats fed traditional diet (Table 5). Pregnancy is characterized by sodium retention and increased extracellular volume necessary for the maintenance of the mother and growth of the foetus (Davison and Lindherimer, 1989). In this context, Digby (2007) demonstrated that the ewes fed a highsalt diet managed the physiological conflict of salt retention for pregnancy and salt excretion for an overload of salt by reducing their plasma aldosterone concentration. When pregnant ewes are fed a normal or low-salt diet, aldosterone is required to increase water re-absorption and thus increase extracellular fluid. When pregnant ewes are fed a high-salt diet, aldosterone is not required as the high salt from the diet results in increased water intake and thus extracellular volume is increased. Therefore pregnant ewes fed high salt were able to avoid complications such as hypertension (Rafestin-Oblin et al., 1991) or neonatal mortalities (Potter and Mclntosh, 1974) by reducing their plasma aldosterone concentration (Digby, 2007). Thus the decline in aldosterone concentrations reported herein was probably the most important adaptive mechanism that allowed the ewes to successfully complete pregnancy while consuming a high-salt diet (Digby, 2007).

The level of aldosterone was decreased from early gestation period and increased in late pregnancy. Aldosterone secretion was in the lowest level when the blood sodium level was increased at early gestation, while the reverse was true during non- gestation (dry period). This emphasized that blood sodium ions mainly regulate aldosterone secretion as stated by Digby (2007). Plasma renin activity (PRA) increases substantially during normal pregnancy (Digby, 2007). Angiotensin II concentrations also increase to nearly twice normal, due to the increase of the renin substrate, angiotensinogen, produced by the liver in response to increased levels of oestrogen whose values are high during that period (Hutchinson-Williams and Decherney 1992). As a result of the increased angiotensin II, aldosterone concentrations increase (Digby, 2007). These data supported by Boulfekhar and Brudieux (1980) who reported increased plasma aldosterone at the end of pregnancy due to the stimulation of rennin substrate production by oestrogens.

\section{CONCLUSION}

It could be concluded from the aforementioned results that halophytic forages are increasingly important for the livestock industry because of the increase in saline land. Introducing salt tolerant plants to Shami goats could be a feasible solution to minimize the problem of animal feed shortage under arid conditions of Southern Sinai. However, feeding such salt tolerant plants during gestation periods may have adverse effects on some physiological parameters.

\section{ACKNOWLEDGMENT}

This study is a part of the regional project titled "Adaptation to climate changes in WANA marginal environments through sustainable crop and livestock diversification" funded by International Center for Biosaline Agricultural (ICBA), UAE. 


\section{REFERENCES}

A.O.A.C. (1985). Official Methods of Analysis. Association of Official Analytical Chemistry. Washington, D. C., USA.

Abd El-Rahman, H.H.; A.M. Kandil; Fatma M. Salman and M.I. Mohamed (2008). Nutritive potential of some browse plants grown under the Egyptian desert conditions of Egypt. J. Agric., Sci., Mansoura Univ., 33(8): 5641-5650.

Abdel-Hafez, M. A. M. (2002). Studies on reproductive performance in sheep. Ph. D. Thesis, Fac. Agric. Zagazig Univ. Egypt.

Abdelrahman, M. M. and R. S. Aljumaah (2012). Metabolic blood profile and milk compositions of periparturient and early lactation periods in sheep. Asian J. Anim.Vet. Adv., 7: 1130-1138.

Abdou, A.R.; E.Y. Eid; Abeer M. El-Essawy; Afaf M. Fayed; H. G. Helal and H. M. El-Shaer (2011): Effect of feeding different sources of energy on performance of goats fed saltbush in Sinai. J. Am. Sci., 7(1):1040-1050.

Abdul-Aziz, G. M.; R. M. El Shaer; A. A. Fahmy; A. S. Shalaby; A. M. Abdel Gawad; R. Rubino and P. Morand-Fehr (2001). Carcass quality of fattened sheep fed halophytic silage with non-conventional energy supplements in Egypt. Options Mediterraneennes: Serie A. Seminaires Mediterraneens, vol. 46, pp. 35-39.

Abu El-Ella, A. A. and O. F. Kommonna (2013). Reproductive performance and blood constituents of Damascus goats as affected by yeast culture supplementation. Egypt. J. Sheep and Goat Sci., 8 (1), P: $171-187$.

Aganga, A. A.; J. K. Mthetho and S. Tshwenyane (2003). Atriplex Nummularia (Old Man Saltbush): A Potential Forage Crop for Arid Regions of Botswana. Pak. J. Nut., 2 (2): 72-75.

Ahmed, M. M.; K. A. Siham and M. E. S. Bari (2000). Macromineral profile in the plasma of Nubian goats as affected by the physiological state. Small Rumin. Res., 38 (3): 249- 254.

Al-Dewachi, O.S. (1999). Some biochemical constituents in the blood serum of pregnant Awassi ewes. Iraqi J. Vet. Sci., 12: 275-279.

Alicata, M. L.; G. Amato; A. B. Bonanno; D. Gimbalo and G. Leto (2002). In vivo digestibility and nutritive value of Atriplex halimus alone and mixed with wheat straw. J. Agric. Sci., 139: 139-142.

Al-Khalasi, S. S.; O. Mahgoub; I. T. Kadim; W. Al-Marzouqi and S. Al-Rawahi (2010). Health and performance of Omani sheep fed salt-tolerant sorghum (Sorghum bicolor) forage or Rhodes grass (Chloris gayana). Small Rumin. Res., 91 (1): 93- 102.

Alsheikh, S. M.; K. M. Youssef; A. A. Fahmy; Abeer M. El-Essawy and H.M. El-Shaer (2012): Growth performance of Barki lambs fed salt-tolerant plants under semi-intensive production system in Sinai. Egypt. J. Nut. Feeds, 15(3): 497-502.

Amer, Z. Hanan; N. H. Ibrahim; G. R. Donia; F. E. I. Younis and Y. M. Shaker (2014). Scrutinizing of trace elements and antioxidant enzymes changes in barki ewes fed salt-tolerant plants under South Sinai conditions. Journal of American Science, 10 (2): 241 - 249.

Anon (2009): Introduction of salt-tolerant forage production systems to salt affected lands in Sinai Peninsula in Egypt: a pilot demonstration project. Final Report, DRC, Egypt- ICBA, UAE.

Antunovic, Z.; D. Sencic; M. Speranda and B. Liker (2002). Influence of the season and reproductive status of ewes on blood parameters. Small Rumin. Res., 45:39-44.

Antunovic, Z.; J. Novoselec; H. Sauerwein; M. Speranda; M. Vegara and V. Pavic (2011). Blood metabolic profile and some of hormones concentration in ewes during different physiological status. Bulg. J. Agric. Sci., 17 (5): 687-695.

Assad, F. and M. M. A. El-Sherif (2002). Effect of drinking saline water and feed shortage on adaptive responses of sheep and camels. Small Rumin. Res., 45: 279-290.

Ayyat, M. S.; A. A. Habeeb and S. M. Bassuny (1991). Effect of water salinity on growth performance, carcass traits and some physiological aspects of growing rabbits in summer season. Egypt J. Rabbit Sci., 1: 21-34.

Azab, M. E. and H. A. Abdel-Maksoud (1999). Changes in some hematological and biochemical parameters during prepartum and postpartum periods in female Baladi goats. Small Rum. Res., $34: 77-85$.

Badawy, M. T. and K. M. Youssef (2008): Impact of feeding systems on physiological, reproductive and productive performance of Shami goats during different physiological stages. Egyptian J. Anim. Prod., 45 (2):101-117. 
Balikci E; A. Yildiz and F. Gurdogan (2007). Blood metabolite concentrations during pregnancy and postpartum in Akkaraman ewes. Small Rumin. Res., 67: 247-251.

Bamerny, A.O. (2013). Changes in some haemato-biochemical and electrolytes parameters in female meriz goats during pregnancy and after parturition. J. Anim. Sci., 2(1): 11-14.

Ban-Tokuda, T.; C. Delavaud; Y. Chilliard and T. Fujihara (2008). Plasma leptin, feed intake and body fat accumulation in fattening castrated male and female lambs. Anim. Sci. J. 79: 58-67.

Bauman, D. E. and W. B. Currie (1980). Partitioning of nutrients during pregnancy and lactation: A review of mechanism involving homeostasis and homeorheosis. J. Dairy Sci., 63: 1514-1529.

Belfield, A. and D. M. Goldberg (1971). Revised assay for serum phenyl phosphayatase activity using 4amino- antipyrine. Enzyme, 12: 561- 573.

Ben Salem, H.; A. Nefzaoui and L. Ben Salem (2002): Supplementing spineless cactus (Opuntia fi cusindica) based diets with urea-treated straw or oldman saltbush (Atriplex nummularia). Effects on intake, digestion and sheep growth. J. Agric. Sci., 138, 85-92.

Ben Salem, H.; H. C. Norman; A. Nefzaoui; D. E. Mayberry; K. L. Pearce and D. K. Revell (2010). Potential use of oldman saltbush (Atriplex nummularia Lindl.) in sheep and goat feeding. Small Rumin. Res., 91: 13- 28.

Boudebza, A.; A. Bensegueni; M. C. Abdeldjelil and C. Belatreche (2014): Some blood biochemical parameter changes in Ouled Djellal ewes during lactation and dry period. Ann. Biol. Res., 5 (3):4245.

Boulfekhar, L. and R. Brudieux (1980). Peripheral concentrations of progesterone, cortisol, aldosterone, sodium and potassium in the plasma of the Tadmit ewes during pregnancy and parturition. J. Endocrinol., 84: 25- 33.

Bravo, L.; E. Manas and F. S. Caixto (1993): Dietary non extractable condensed tannins as indigestible compound. Effect on fecal weight and protein and fat excretion. J. Sci. Food Agric., 63: 68.

Chadwick, M. (2009): Fetal programming of sheep for production on saltbush. $\mathrm{Ph}$. D. Thesis of Animal Science. The University of Western Australia. Faculty of Natural and Agricultural Sciences School of Animal Biology.

Cheeke, P. R. (1995). Endogenous toxins and mycotoxins in forage grasses and their effect on livestock. J. Anim. Sci., 73: 909- 918.

Clark, E. G. C. and M. L. Clark (1978). Veterinary toxicology. Bailliere Tindall, London.

Coles, E. H. (1986). Veterinary Clinical Pathology. $4^{\text {th }}$ Ed. Sunders W. B. Co., Philadelphia, London.

Davison J. M. and M. D. Lindheimer (1989). Volume homeostasis and osmoregulation in human pregnancy. Baill. Clin. Endocrinol. Metab., 3: 451-472.

Digby S. N.; D. G. Masters; D. Blache; M. A. Blackberry; P. I. Hynd and D. K. Revell (2008). Reproductive capacity of Merino ewes fed a high-salt diet. Animal, 2: 1353-1360.

Digby, S. (2007). High dietary salt during pregnancy in ewes alters the responses of offspring to an oral salt challenge. Ph. D. Thesis .The University of Adelaide, Australia.

Donia, G.R.; N. H. Ibrahim; Y. M. Shaker; F. M. Younis and Hanan Z. Amer (2014). Liver and kidney functions and blood minerals of Shami goats fed salt tolerant plants under the arid conditions of southern Sinai, Egypt, J. Am. Sci., 10 (3): 49-59.

Donovan, D. S.; C. G. Solomon; E. W. Seely; G. H. Williams and D. C. Simonson (1993). Effect of sodium intake on insulin sensitivity. Am. J. Physiol. Endocrinol. Metab., 264: 730 -734.

Doumas, B. T.; W. A. Watson and H. G. Biggs (1971). Albumin standards and the measurement of serum albumin with bromcresol green. Clin. Chem. Acta, 31: 87- 96.

El Shaer, H. M. (2000). Potentiality of animal production in the Egyptian desert region. In: Proceedings of the Conference on Animal Production in the $21^{\text {st }}$ Century Challenges and Prospects, 18-20 April 2000, Sakha, Kafr El Sheikh, Egypt, pp. 93-105.

El Shaer, H. M. (2003). Potentiality of halophytes as animal fodders under arid conditions of Egypt. Tasks for Veget. Sci., 38: 111-119 
El Shaer, H. M. (2006). Halophytes as such crops from feeds in arid and semi-arid regions. In: Ozturk, M., Waisel, Y., Khan, M. A., Gork, G. (Eds.), Biosaline Agriculture and High Salinity Tolerance in Plant. Birkhauser, Basel, pp. 117-128.

El-Bassiony, M. F. (2013). Productive and reproductive responses of growing Shami goat kids to prolonged saline conditions in South Sinai. Ph. D. Thesis, Fac. of Agric., Cairo Univ., Giza, Egypt.

Elnageeb, M. E. and A. M. Abdelatif (2010). The minerals profile in Desert Ewes (Ovis aries): Effects of pregnancy, lactation and dietary supplementation. Am. Eur. J. Agric. Environ. Sci., 7 (1): 18- 30.

El-Sherif, M. M. A. and F. Assad (2001). Changes in some blood constituents of Barki ewes during pregnancy and lactation under semi arid conditions. Small Rum. Res., 40 (3): 269- 277.

Fawcett, J. K. and J. E. Soctt (1960). A rapid precise method for the determination of urea. J. Cline., Path. 13: 156.

Fayed, A. M. (2009). In vitro and In vivo evaluation of biological treated salt plants. Am. Eur. J. Agric. Environ. Sci., 6 (1): 108 - 118.

Fayed, A. M.; A. M. El- Essawy; E. Y. Eid; H. G. Helal; A. R. Abdou and H. M. El Shaer (2010). Utilization of berseem and atriplex for feeding sheep under saline conditions of South Sinai, Egypt. J. Am. Sci., 6 (12): 1447- 1461.

Ferrell, C. L. (1991). Maternal and fetal influences on uterine and conceptus development in the cow: II. Blood Flow and nutrient flux. J. Anim. Sci., 69, 1954-1965.

Firat, A. and A. Ozpinar (1996). The study of changes in some blood parameters (glucose, urea, bilirubin AST) during and after pregnancy in association with nutritional conditions and litter size in ewes. Turk. J. Vet. Anim. Sci., 20: 387-393.

Firat, A. and A. Ozpinar (2002). Metabolic profile of pre-pregnancy, pregnancy and early lactation in multiple lambing Sakiz ewes. 1. Changes in plasma glucose, 3-hydroxybutyrate and cortisol levels. Ann. Nutr. Metab., 46: 57-61.

Francis, G.; Z. Kerem; H. P. S. Makkar and K. Becker (2002). The biological action of saponins in animal systems: a review. Br. J. Nut., 88: 587-605.

Gale, S. M., V. D. Castracane; C. S. Mantzoros (2004). Energy homeostasis, obesity and eating disorders: recent advances in endocrinology. J. Nutr. 134: 295- 298.

Gornal, A. C.; C. J. Bardawill and M. M. David (1949). Kit protein Egyptian American Co. for Laboratory Services. J. Biol. Chem., 177: 751-755.

Gürgöze, S. Y.; A. K. Zonturlu; N. Özyurtlu and H. Içen (2009): Investigation of Some Biochemical Parameters and Mineral Substance during Pregnancy and Postpartum Period in Awassi Ewes. Kafkas Univ Vet Fak Derg., 15 (6): 957-963.

Hafez A. M.; H. İbrahim; A. Gomma; A. A. Farrag and I. A, Salem (1983). Enzymatic and hematological studies in buffalo at periparturient periods. Assiut Vet Med J., 11: 173-175.

Han, L.K.; B. J. Xu; Y. Kimura; Y. N. Zheng and H. Okuda, H. (2000): Platycodi radix affects lipid metabolism in mice with high fat diet induced obesity. J. Nut., 130:2760-2764.

Herdt, T. H.; W. Rumbeiha and W. E. Braselton (2000). The use of blood analyses to evaluate mineral status in livestock. Veterinary Clinics of North America: Food Anim. Pract., 16: 423-444.

Hussein, N. M. (1987). Hematological studies on sheep drinking salty water. M. Sc. Thesis, Faculty of Science, Al- Azhar University, Cairo, Egypt.

Hutchinson-williams K. A. and Decherney A. H. (1992). The endocrinology of pregnancy, 97- 114, 1n Medicine of the Fetus and Mother. Eds. EA Reece, et al., JB

Ibrahim, S. M. N. (1995). Clinicopathological studies in goats drinking salty water under desert conditions. M. V. Sc., Cairo Univ.

ICBA (2006). Biosalinity news. Newsletter of the International Center of Biosaline Agriculture (ICBA) 9 (July (2)), 2006.

Iriadam, M. (2007). Variation in certain haematological and biochemical parameters during the peripartum period in Kilis does. Small Rumin. Res., 73: 54-57. 
Isganaitis, E. and R. H. Lustig (2005). Fast food, central nervous system insulin resistance, and obesity. Arterioscl. Thromb. Vasc. Biol., 25: 2451-2462.

Jacob, N. and V. P. Vadodaria (2001). Levels of glucose and cortisol in blood of Patanwadi ewes around parturition. Ind. Vet. J., 78: 890-892.

Jainudeen, M. R. and E. S. E. Hafez (1989): Gestation, prenatal physiology and parturition. (Gestación, fisiología prenatal y parto). In E. S. E. Hafez (Editor), Artificial Domestic Animal reproduction and Insemination (Reproducción e Inseminación Artificial en Animales Domésticos). $5^{\text {th }}$ ed., Interamericana, México, 203-224.

Jainudeen, M. R. and E. S. E. Hafez (1994). gestation, prenatal physiology and parturition. In: Reproduction in Farm Animals. Lea and Febiger, Philadelphia, 247-283.

Kaneko, J. J. (1989). Clinical Biochemistry of Domestic Animals. $4^{\text {th }}$ ed. Academic Press.

Kaneko, J. J.; J. W. Harvey; M. L. Brus and J. W. Harvey (2008). Clinical Biochemistry of Domestic Animals. $6^{\text {th }}$ ed. Elsevier/Academic Press, Amsterdam.

Karapehlivan, M., A.; O. Atakis; R. Atakisi; S. Yucayurt and S. M. Pancarci (2007). Blood biochemical parameters during the lactation and dry period in Tuj ewes. Small Rumin. Res., 73: 267-271.

Kaushik, H. K, and N. S. Bugalia (1999). Plasma total protein, cholesterol, minerals and transaminases during pregnancy in goats. Ind. Vet. J.; 76: 603-606.

Kearl, I. C. (1982). Nutrients requirements in developing countries. Utah Agric. Exp. Stat., Utah State Unviersity, Logan, USA.

Khan, J. R. and R. S. Ludri (2002). Changes in blood glucose, plasma non-esterified fatty acids and insulin in pregnant and non-pregnant goats. Trop. Anim. Health Prod., 34 (1):81-90

Khatun, A.; G. M. Wani; J. I. A. Bhat; A. R. Choudhury and M. Z. Khan (2011). Biochemical indices in sheep during different stages of pregnancy. Asian J. Anim. Vet. Adv., 6(2): 175-181.

Kincaid (2008). Changes in the Concentration of Minerals in Blood of Peripartum Cows. Mid-South Ruminant Nutrition Conference. 1-8.

Korshom, M.; S. A. Hattab and A. A. Mandour (1993). Some biochemical studies in the blood of Egyptian buffalo-cows during last week of pregnancy and four weeks post-partum. Bni-Suf Vet. Med. Res., 3 (1): 43-50.

Kulcu, R. and F. Yur (2003). A study of some serum mineral levels before and during pregnancy and during lactation period of sheep and cattle. Biol. Trace Elem. Res., 92 (3): 275- 279.

Lockitch, G. (1997). Clinical biochemistry of pregnancy. Crit. Rev. Clin. Lab. Sci., 34 (1): 67-139.

Louacini, B. K.; A. Dellal; M. Halbouche and K. Ghazim (2012). Effect of incorporation of the spineless Opuntia ficus Indica diets on biochemical parameters and its impact on the average weight of ewes during the maintenance. Global Vet., 8(4): 352-359.

Magistrelli, D.; G. Polo Dimel; F. Rosi (2008). Leptin, insulin and ghrelin levels in goat milk and in plasma of suckling kids. Small Rumin. Res., 79: 38-41.

Manish-Mahawar; A. K. Jam and Puneet-Kumar (2004). Clinically important enzymes in Jamunapari and Marwari goats. Indian J. Anim. Sci., 74: 924-925.

Mashudi; I. M. Brooke; C. W. Holmes and G. F. Wilson (1997). Effect of Mimosa bark extracts containing condensed tannins on rumen metabolism in sheep and milk production by grazing cows. Proceeding o the New Zealand Society of Anim. Prod., 57: 126.

Masters, D. G.; A. J. Rintoul; R. A. Dynes; K. L. Pearce and H. C. Norman (2005). Feed intake and production in sheep fed diets high in sodium and potassium. Aust. J. Agric. Res., 56: 427-434.

Michell, A.R. (1985). Sodium and research in farm animals: problems of requirement, deficit, and excess. Outlook Agric., 14: 179- 182.

Mohamed, M. I. (1996). Studies on desert roughages on camels and small ruminants nutrition. Ph. D. Thesis, Faculty of Agriculture, Cairo University. 
Mondal, S.; A. Minj; M. C. Pathak; D. N. Singh and V. P. Varshney (2014). Importance of hormonal changes during the periparturition period in black Bengal goats. Int. J. Clin. Exper. Physiol., 1(1): $20-25$.

Mufti, A. M.; G. M. Wani; N. A. Wani; B. A. Buchoo and M. Z. Khan (2000). Prenatal development of ovine fetus. Small Rumin. Res., 38: 87-89.

Muller, H. M.; E. Leinmuller and U. Rittner (1989). Effect of tanniferous plant material on protein and carbohydrate degradation in rumen fluid in vitro. In Recent Advance of Research. In Antinutritional Factors in Lequme Seeds. (Huisman, J.; Van der Poel, T. F. B. and Liener, I. E. eds.), pp. 156- 159, Wageningen.

Nasr, S. M; E. A. Ibrahim; A. Bakeer and M. I. Dessouky (2002). Clinicopathological and histopathological studies in goats fed on Atriplex halimus raised in the Egyptian desert. International Symposium on Optimum Resources Utilization in Salt - Affect Ecosystems in Arid and Semi- arid Regions. Cairo, 8- 11, April, 515- 525.

Nawaz, S.; S. J. Hanjra and R. H. Qureshi (1994). Effect of feeding Atriplex amnicola on growth and carcass quality of dwarf goats. In: Squires, VR, Ayoub, AT (eds.), "Halophytes as a resource for livestock and for rehabilitation of degraded lands", Kluwer Academic Publishers, Dordrecht, pp. 277280.

NRC (2007). Nutrient requirements of small ruminants: sheep, goats, cervids, and New World camelids. National Research Council of the National Academies, National Academies Press, Washington, D.C., U.S.A.

Ogihara, T.; T. Asano; K. Ando; Y. Chiba; N. Sekine; H. Sakoda; M. Anai; Y. Onishi; M. Fujishiro; H. Ono; N. Shojima; K. Inukai; Y. Fukushima; M. Kikuchi and T. Fujita (2001). Insulin resistance with enhanced insulin signaling in high-salt diet-fed rats. Diabetes, 50: 573-583.

Ortiz, L. T.; C. Centeno and J. Tervino (1993). Tannins in faba bean seeds: effect on the digestion of protein and amino acids in growing chicks. Anim. Feed Sci. Technol., 41: 271- 278.

Piccione, G.; G. Caola; C. Giannetto; F. Grasso; S. Calanni Runzo; A. Zumbo and P. Pennisi (2009). Selected biochemical serum parameters in ewes during pregnancy, post-parturition, lactation and dry period. Animal Science Papers and Reports, 27(4): 321-330. Institute of Genetics and Animal Breeding, Jastrzebiec, Poland.

Potter, B. J. and G. H. McIntosh (1974). Effect of salt water ingestion on pregnancy in the ewe and on lamb survival. Aust. J. Agric. Res., 25: 909-917.

Potter, S. M.; R. Jimenez-Flores; J. Pollack; T. A. Lone and M. D. Berber-Jemenez (1993). Protein saponin interaction and its influence on blood lipids. J. Agric. Food Chem. 41: 1287-1291.

Rafestin-Oblin, M. E.; B. Couette; C. Barlet-Bas; L. Cheval; A. Viger and A. Doucet (1991). Renal action of progesterone and 18- substituted derivatives. Amer. J. Physiol. Renal Physiol., 260: 828 -832.

Ramin, A. G.; S. Asri-Rezaie and S. A. Macali (2007). Evaluation on serum glucose, BHB, urea and cortisol in pregnant ewes. Medycyna Wet, 63 (6): 674-677.

Reitman, S. M. D. and S. Frankel (1957). A colorimeter method for determination of serum glutamic oxaloacetic acid and glutamic pyruvic acid transfereases. Am. J. Clin. Path., 28: 56- 63.

Roeschlau, P.; E. Bernt and W. Gurber (1974). Enzymatic determination of total cholesterol in serum. Zklin. Chem. Klin. Biochem., 12 (5) 226.

Romero, M. J.; J. Madrid; F. Hernandez and J. J. Ceron (2000). Digestibility and voluntary intake of vine leaves (vitis vinifera L.) by sheep. Small Rumin. Res., 38: (2): 191- 195.

Roubies, N.; N. Panousis; A. Fytianou; P. D. Katsoulos; N. Giadinis and H. Karatzias (2006). Effects of age and reproductive stage on certain serum biochemical parameters of chios sheep under greek rearing conditions. J. Vet. Med. A, 53: 277-281.

Ruchebusch, Y.; P. Louis- Philippe and R. Dunlop (1991). Lactation. In: Physiology of small and large animals. (Editor: B.C. Decker), Philadelphia, USA., pp: 615- 631.

Saeed, A.; I. A. Khan and M. M. Hussein (2009). Change in biochemical profile of pregnant camels (Camelus dromedarius) at term. Comp. Clin. Pathol., 18 (2): 139- 143. 
Safsaf, B.; M. Tlidjane; B. Mamache; M. A. Dehimi; H. Boukrous and A. H. Aly (2012). Influence of Age and Physiological Status on Progesterone and Some Blood Metabolites of Ouled Djellal Breed Ewes in East Algeria. Global Vet., 9 (2): 237-244.

SAS Institute (2004). Statistical Analysis System, STAT/ user's guide, Release 9.1, SAS Institute, Cary NC. USA.

Schirmeister, J.; H. Willmann; H. Kiefer and W. Hallauer (1964): Fuer und wider die brauchbarkeit der endogenen hrea tininclearance der fanktionellen nierendiagnostik. Dtsch. Med. Woschr, 89 (9):16401647.

Schlumbom C.; H. P. Sporleder; H. Gurtler and J. Harmeyer (1997). The influence of insulin on metabolism of glucose, free fatty acids and glycerol in normo- and hypocalcaemic ewes during different reproductive stages. Deutsche Tierarztliche Wochenschrift, 104: 359-365.

Shahen, G. F.; A. A. Zaki and H. M. Yousef (2004). Effect of feeding level on growth nutrient digestibility and feed efficiency for buffalo calves. Egypt. J. Nut. Feeds, 7, 11-.

Shaker, Y. M. (2014). Live body weight changes and physiological performance of Barki sheep fed salt tolerant fodder crops under the arid conditions of southern Sinai, Egypt. J. Am. Sci., 10 (2s):78- 88.

Shaker, Y. M.; N. H. Ibrahim; F. E. Younis and H. M. El Shaer (2014). Effect of feeding some salt tolerant fodder shrubs mixture on physiological performance of Shami goats In southern Sinai, Egypt. J. Am. Sci., 10 (2s): 66 -77

Shaker, Y. M.; S. S. Abou El-Ezz and A. L. Hashem (2008). Physiological performance of Barki male lambs fed halophytes under semi-arid conditions. J. Agric. Sci. Mansoura Univ., 33 (9): 6393- 6408.

Sharma, A.; P. Kumar; M. Singh and N. K. Vasishta (2015). Haemato-biochemical and endocrine profiling of north western Himalayan Gaddi sheep during various physiological/reproductive phases. Open Vet. J., 5(2): 103-107.

Simsek, O.; S. Arikan and M. Cinar (2015): Reference values for selected hematological and biochemical blood parameters from pre-pregnancy to advanced gestation in Angora cats. Turk. J. Vet. Anim. Sci., 39: 29-33.

Soliman, G. A. and A. M. Donia (2015): Antihyperglycemic, Antihyperlipidemic and Antioxidant effect of Atriplex farinosa and Atriplex nummularia in Streptozotocin-induced Diabetes in rats. Bull. Env. Pharmacol. Life Sci., 4 (12): 10-18.

Streeter, M. N.; G. M. Hill; D. G. Wagner; F. N. Owens and C. A. Hibberd (1993). Effect of bird resistant and non bird resistant sorghum grain on amino acid digestion by beef heifers. J. Anim. Sci., 71: 1648- 1656.

Sunderman, F. W. Jr. and F. W. Sunderman (1958). Colorimetric determination of potassium in serum and plasma. Am. J. Clin, Pathol, 29: 95.

Taghipour, B.; H. A. Seifi; M. Mohri; N. Farzaneh and A. Naserian (2010). Variations of energy related biochemical metabolites during peri-parturition period in fat-tailed Baloochi breed sheep. Iran. J. Vet. Sci. Technol., 2 (2): 85- 92.

Tata, J. R. and C. C. Widnell (1966). Ribonucleic and synthesis during the early action of hormone. Biochem., 98: 604.

Tietz, N. W. (1986). Textbook of clinical chemistry. W. B. Saunders Co. London, Philadelphia, pp. 796.

Trinder, P. (1951). A rapid method for the determination of sodium in serum. Analyst, 907: 596- 599.

Tripathy, K. C.; B. K. Sahu; N. C. Panda and B. C. Nayak (1984). Toxicity of tannin acid in goats. Ind. J. Anim. Sci., 54 (11): 1091- 1093.

Underwood, E. J. and N. F. Suttle (1999). The mineral nutrition of livestock. $3^{\text {rd }}$ Edition. Chapter 1 . New York, USA.

Van Saun, R. (2000). Blood profiles as indicators of nutritional status. In: Proc. $18^{\text {th }}$ Annu. Western Canadian Dairy Seminar. Red Deer, Alberta, Canada, pp.1-6.

Vernon, R.G.; R. A. Clegg and D. J. Flint (1981). Metabolism of sheep adipose tissue during pregnancy and lactation. Biochem. J., 200: 307-314. 
Vihan V. S. and P. Rai, (1983). Metabolic profiles at different physiological stage in sheep and goat. Ind. J. Vet. Med., 3: 1-8.

Waziri, M. A.; A. Y. Ribadu and N. Sivachelvan (2010). Changes in the serum proteins, hematological and some serum biochemical preofiles in the gestation period in the Sahel goats. Vet. Arhiv, 80 (2): 215- 224.

Weeth, H. J. and L. H. Haverland (1961). Tolerance of growing cattle for drinking water containing sodium chloride. J. Anim. Sci., 20: 518- 521.

Wichell, A. R. (1976). Relationships between individual difference in salt appetite of sheep and their plasma electrolyte sates. De. Med. Royal- Vet., 17: 215.

Yokus, B.; D.U. Cakir; Z. Kanay; T. Gulten and E. Uysal (2006). Effects of seasonal and physiological variations on the serum chemistry, vitamins and thyroid hormone concentrations in sheep. Journal of Veterinary Medicine, 53: 271-276.

Zarkawi, M. and A. Soukouti (2005). Serum progesterone levels using radioimmunoassay during oestrous cycle of indigenous Damascus does. New Zealand J. Agric. Res., 44: 165-169.

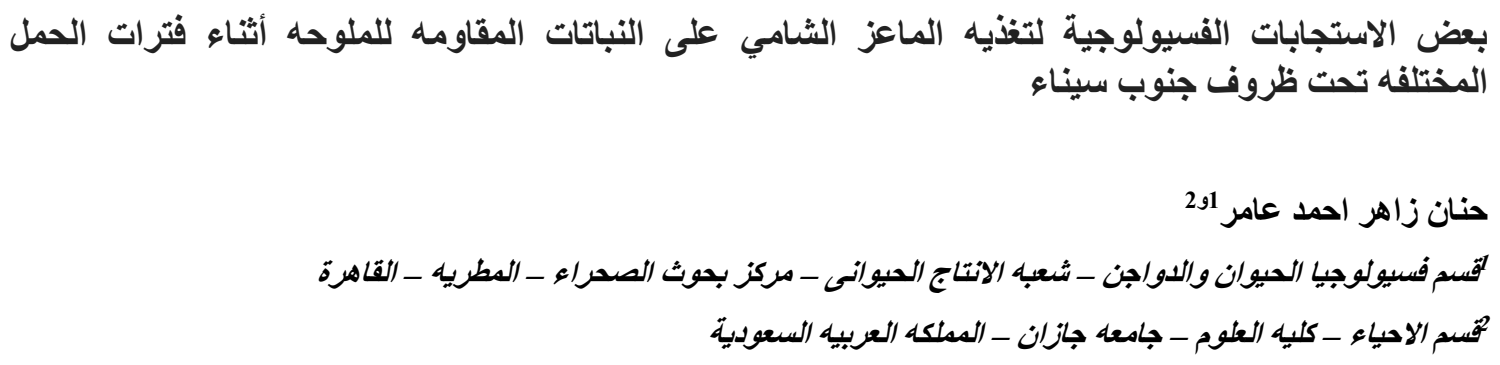

